DOI: https://doi.org/10.24127/ajpm.v10i2.3661

\title{
KEMAMPUAN PEMECAHAN MASALAH MATEMATIKA DITINJAU DARI PERBEDAAN GENDER
}

\author{
Widi Lestari $^{{ }^{*}}$, Tri Atmojo Kusmayadi ${ }^{2}$, Farida Nurhasanah ${ }^{3}$ \\ ${ }^{1 * 3}$ Fakultas Keguruan dan Ilmu Pendidikan, Universitas Sebelas Maret, Indonesia \\ ${ }^{2}$ Fakultas Matematika dan Imu Pengetahuan Alam, Universitas Sebelas Maret, Indonesia \\ *Corresponding author. \\ E-mail: $\quad$ widilestari01@student.uns.ac.id ${ }^{\left.{ }^{*}\right)}$ \\ tri.atmojo.kusmayadi@staff.uns.ac.id ${ }^{2)}$
}

Received 03 April 2021; Received in revised form 14 June 2021; Accepted 29 June 2021

\begin{abstract}
Abstrak
Penelitian ini bertujuan untuk menganalisis kemampuan pemecahan masalah siswa ditinjau dari perbedaan gender. Metode penelitian menggunakan penelitian kualitatif. Subjek pada penelitian ini adalah kelas XI TLM A SMK Maarif NU 2 Ajibarang Kab Banyumas. Penentuan sampel menggunakan teknik purposive sampling yaitu dengan pemberian soal pada seluruh siswa kelas XI TLM A. Kemudian diambil 8 siswa sebagai sampel karena memenuhi sesuai indikator kemampuan pemecahan masalah matematika. Indikator kemampuan pemecahan masalah matematika yang diambil adalah memahami masalah, melaksanakan rencana, merencanakan penyelesaian dan memeriksa proses dan hasil. Hasil penelitian menunjukan bahwa pada tingkat memahami masalah, siswa laki-laki lebih baik dari pada perempuan sehingga siswa laki-laki mampu mencapai tingkat memahami masalah dengan baik sehingga mampu menyebutkan apa yang diketahui dan ditanyakan pada soal dengan jelas. Siswa pada tingkat melaksanakan rencana, Siswa perempuan dan laki-laki pada tingkat ini sudah dapat dikatakan mampu mencapai dengan baik karena terbukti pada jawaban siswa yang menunjukkan bahwa siswa mengaplikasikan apa yang telah guru ajarkan. Siswa pada tingkat merencanakan penyelesaian siswa siswa laki-laki dan perempuan belum mampu menyimpulkan sesuatu yang ada menurut hasil yang telah diketahui maka belum mampu mencapai tingkat merencanakan penyelesaian. Siswa pada tingkat memeriksa proses dan hasil, siswa perempuan lebih mampu mencapai tingkat memeriksa proses dan hasil terbukti dengan ketelitian yang ada pada jawaban siswa. Siswa laki-laki kurang teliti saat menghitung bilangan pada matriks pengurangan.
\end{abstract}

Kata kunci: Gender, Kemampuan Pemecahan Masalah, Matematika

\begin{abstract}
This study was aimed at analysing students' problem-solving abilities observed through gender differences. The method used in this study was qualitative method. The subjects in this study were eleventh grade students of TLM A SMK Maarif NU 2 Ajibarang, Banyumas. The technique used to determine sample was purposive sampling technique which was conducted by giving questions to all students of class XI TLM A. Then 8 students were taken as samples since they met the appropriate indicators of mathematical problem solving ability taken are understanding problems, implementing plans, planning results and checking processes and results. The results showed that at the level of understanding problem, male students were better than female students therefore male students were able to reach the level of understanding problem well and they were able to state what was known and asked on the questions clearly. At the level of implementing plan, male and female students were considered have been able to reach the level well and it could be proven by their answers which showed that they were able to apply what was taught by the teacher. At the level of planning completion, male and female students have not been able to make conclusion based on the result has been obtained. Therefore male and female students in this level have not achieved the level of planning completion. The students at the level of examining process and result, female students were better than male students. It was proven by the carefullness found on the students' answer. Male students were careless in calculating numbers on the subtraction matrix.
\end{abstract}

Keywords: Gender, Mathematical, Problem Solving Ability

This is an open access article under the Creative Commons Attribution 4.0 International License 
DOI: https://doi.org/10.24127/ajpm.v10i2.3661

\section{PENDAHULUAN}

Matematika merupakan bagian penting dari pendidikan nasional dan merupakan salah satu ilmu universal yang mendasari perkembangan teknologi modern. Dalam pembelajaran matematika, terdapat beberapa kemampuan yang harus dimilliki oleh siswa yaitu pemecahan masalah, pemahaman konsep, koneksi matematika, komunikasi matematika dan representasi matematika. Berdasarkan beberapa kemampuan tersebut, kemampuan pemecahan masalah menjadi salah satu fokus dalam pembelajaran matematika. Pemecahan masalah merupakan konsep yang paling efektif untuk kontekstualitas dan rekontekstualitas konsep, untuk operasional dan transfer dasar pengetahuan matematika, dan untuk memastikan pembelajaran yang berkelanjutan serta bermakna (Capriora, 2015). Oleh karena itu, kemampuan pemecahan masalah matematis memiliki peranan yang sangat penting dalam tercapainya tujuan pendidikan matemati-ka di sekolah karena akan menjadi bekal bagi siswa, bukan hanya di sekolah pada saat pembelajaran namun juga untuk menghadapi kehidupan di masyarakat (Azizah, 2015; Nurhayati, Mulyana, \& Martadiputra, 2016).

Berdasarkan hasil analisis oleh Programme for International Student Assessment (PISA) dan (Trend in International Mathematics and Science) TIMSS, menyatakan bahwa kemampuan siswa Indonesia dalam menyelesaikan masalah non rutin masih rendah, walaupun siswa Indonesia lebih bagus dalam hal menyelesaikan soal-soal berupa fakta dan procedural (Putra \& Novita, 2014). Hal yang sama juga di jelaskan berdasarkan data OECD dalam PISA 2009, 76,7\% siswa di Indonesia hanya mampu menyelesaikan soal matematika pada level 2 atau di bawahnya. Hal ini menunjukan bahwa kemampuan pemecahan masalah siswa Indonesia masih tergolong rendah. Berdasarkan hasil observasi dan wawancara yang dilakukan melalui google classroom dan zoom meeting di kelas XI SMK Maarif NU 2 Ajibarang menunjukan bahwa $75 \%$ siswa yang pasif saat pembelajaran dan hanya ada $25 \%$ siswa yang sudah aktif bertanya dan mengerjakan latihan soal yang diberikan guru. Siswa yang pasif saat pembelajaran tidak mau menyampaikan pada guru bahwa mereka sudah paham atau belum terhadap materi yang disampaikan. Pada saat akhir pembelajaran guru memberi soal latihan yang mengacu pada kemampuan pemecahan masalah agar siswa dapat melatih kemampuannya sampai dimana siswa memahami langkah-langkah dalam menyelesaikan soal itu sebagai tugas namun hanya beberapa yang mengirimkan hasil pekerjaan mereka. Tidak semua siswa mampu dan paham bagaimana memahami suatu permasalahan kemudian menentukan rencana pemecahan masalah tersebut sampai didapat jawaban yang tepat. Guru harus dengan jelas menjelaskan langkahlangkah penyelesaian soal pada saat memberi contoh soal agar saat siswa diberi soal latihan siswa lebih mudah memahami dan mampu memecahkan masalah matematika itu dengan langkah-langkah yang tepat. Menurut guru matematika pencapaian tersebut masih dirasa kurang memuaskan karena siswa masih kurang tepat dan lengkap dalam menjawab atau menyelesaikan permasalahan. Kurang tepat dan lengkapnya siswa dikarenakan siswa kurang memahami langkah-langkah dalam penyelesaian masalah, maka guru harus lebih banyak lagi memberi contoh soal atau membahas soal-soal yang 
mengarah pada soal latihan agar siswa dapat memberi jawaban yang tepat saat diberi soal latihan. Pada dasarnya setiap manusia diciptakan berbeda beda dalam menyelesaikan masalah, salah satunya karena faktor perbedaan gender yaitu antara laki laki dan perempuan. Kemampuan pemecahan masalah matematika antara laki-laki dan perempuan memiliki perbedaan, perbedaannya terletak dari bagaimana cara siswa laki-laki dan siswa perempuan dalam menyelesaikan soal, sehingga terjadi kesenjangan antara tingkat partisipasi laki-laki dan perempuan. Perbedaan gender bukan hanya berakibat pada perbedaan kemampuan dalam matematika, tetapi cara memperoleh pengetahuan matematika juga terkait dengan perbedaan gender (Gurun, Kubang, \& Agam, 2018).

Berdasarkan hasil ulasan di atas, penting untuk menganalisis kemampuan pemecahan masalah matematika siswa ditinjau dari perbedaan gender. Beberapa penelitian terdahulu telah melakukan penelitian dalam menganalisis kemampuan pemecahan masalah siswa (Agoestanto, Arief, \& Safitri, 2013; Azizah, 2015; Gunur, Alberta, \& Apolonia, 2018; Imamah \& Toheri, 2014; Kusumawati, 2014; Mita, Tambunan, \& Izzati, 2019; Ngaeni \& Saefudin, 2017; Ramadhani, 2017; Simanjuntak, Hia, \& Manurung, 2019; Yurniati \& Wahyuningrum, 2015) Namun belum menganalisis kemampuan pemecahan masalah berdasarkan perbedaan gender, padahal melihat kemampuan seseorang berdasarkan perbedaan gender nya penting untuk diketahui (Diandita, Johar, \& Abidin, 2017; Fitriani, Jalmo, \& Yolida, 2015; Rahayuningsih \& Feriyanto, 2018; Siswati, Susilo, \& Mahanal, 2016; Subarinah, 2013; Tao \& Michalopoulos, 2020; Utami \& Anitra,
2020; Winata \& Friantini, 2020). Oleh karena itu, penelitian ini bertujuan untuk menganalisis kemampuan pemecahan masalah matematika siswa pada materi matriks yang ditinjau dari perbedaan gender siswa kelas XI SMK Maarif NU 2 Ajibarang Kab. Banyumas.

\section{METODE PEENELITIAN}

Metode penelitian yang digunakan adalah penelitian kualitatif. Subjek pada penelitian ini adalah kelas XI TLM A SMK Maarif NU 2 Ajibarang Kab Banyumas yang berjumlah 25 siswa (21 siswa perempuan dan 4 siswa laki-laki). Penentuan sampel menggunakan teknik purposive sampling yaitu dengan pemberian soal pada seluruh siswa kelas XI TLM A. Kemudian diambil jawaban siswa untuk dijadikan sebagai sampel yang terdiri dari 4 perempuan dan 4 laki-laki karena memenuhi kriteria tertentu yaitu diklasifikasikan sesuai indikator kemampuan pemecahan masalah matematika. Indikator kemampuan pemecahan masalah matematika yang diambil adalah memahami masalah, melaksanakan rencana, merencanakan penyelesaian dan memeriksa proses dan hasil. Intrumen yang digunakan berupa tes kemampuan pemecahan masalah matematis dalam bentuk tes uraian yang terdiri dari 3 soal mengenai materi matriks.

Dalam penelitian ini, siswa diberikan materi mengenai Matriks penjumlahan, pengurangan, perkalian, determinan dan diberi latihan soal pada akhir pembelajaran. Jawaban siswa dari latihan soal tersebut yang akan dianalisis untuk mengetahui mana yang lebih baik kemampuan pemecahan masalah matematika siswa laki-laki atau siswa perempuan.

Pada penelitian ini validitas data menggunakan metode triangulasi. 
Penelitian menggunakan sumber data yang berbeda-beda untuk suatu data atau informasi yang sama. Sumber data yang dimaksudkan dapat berupa sumber data yang sejenis maupun sumber data yang berbeda jenis (Budiyono, 2017). Teknik analisis data dalam penelitian ini terdiri dari mereduksi data (merangkum, memilih hal-hal pokok yang penting, mencari tema dan pola serta membuang hal yang tidak penting), penyajian data, dan penarikan kesimpulan atau verifikasi (rangkaian analisis data kualitatif sehingga dapat lebih mempermudah alur analisis yang saling terkait satu sama lain mulai dari awal hingga akhir).

\section{HASIL DAN PEMBAHASAN}

Berikut ini merupakan hasil pekerjaan siswa perempuan dan laki- laki berdasarkan tes pemecahan masalah matematis dan analisisnya.

\subsection{Memahami Masalah}

Berdasarkan hasil tes proses berpikir dalam pemecahan masalah matematis siswa untuk tingkat memahami masalah, siswa laki-laki mampu mencapai tingkat memahami masalah dengan baik sehingga mampu menyebutkan apa yang diketahui dan ditanyakan pada soal dengan jelas. Namun berbeda dengan siswa perempuan yang masih belum mencapai tingkat memahami masalah karena siswa perempuan langsung pada pengerjaan soal. Berikut merupakan salah satu contoh perwakilan dari jawaban siswa laki-laki (Gambar 1) dan jawaban siswa perempuan (Gambar 2) dalam tingkat memahami masalah.

\begin{tabular}{|c|c|}
\hline \multicolumn{2}{|c|}{ 1) Matriks $A\left(\begin{array}{ll}3 & -2\end{array}\right) B\left(\begin{array}{ll}4 & 3\end{array}\right)$ dan $C\left(\begin{array}{ll}4 & 10\end{array}\right)$} \\
\hline$\left(\begin{array}{ll}4 & -1\end{array} \mid\left[\begin{array}{ll}-2 & -1\end{array} \mid\right.\right.$ & $c\left(\begin{array}{ll}4 & 10 \\
9 & 12\end{array}\right)$ \\
\hline nilai determinan $A B-t$ ! & $A B:(3-2)(43)=(3 \times 4(-2) \times(-2) \quad 3 \times 3(2) \times(-1)$ \\
\hline Diket: $A=\left(\begin{array}{ll}3 & -2\end{array}\right)$ & $(4-1)(-2-1) \mid 4 \times 4[-1 \times(-2)(-4) \times(3) \mid 1 \times(-1)$ \\
\hline$\left[\begin{array}{ll}4 & -1\end{array}\right]$ & $\div(12+49+2)=\left(\begin{array}{ll}16 & 11\end{array}\right)$ \\
\hline$B:\left(\begin{array}{ll}4 & 3\end{array}\right)$ & $\left.\left(\begin{array}{ll}16+2 & 12+1\end{array}\right) \begin{array}{ll}128 & 13\end{array}\right)$ \\
\hline$\left[\begin{array}{ll}-2 & -1\end{array}\right]$ & $A B-\left[:(1611)-\left(\begin{array}{ll}1 & 10\end{array}=: 12 \quad 1\right)\right.$ \\
\hline$C:\left(\begin{array}{ll}4 & 10\end{array}\right)$ & $\left(\begin{array}{ll}18 & 13\end{array}\right)\left(\begin{array}{ll}9 & 12\end{array}\right)\left(\begin{array}{ll}9 & 1\end{array}\right)$ \\
\hline $\operatorname{lo} 12$ & $D_{\ell}+A B-C=(121)=(12.1)-(1.9)$ \\
\hline Ditanya : nilai determuan $A B-\tau$ ! & $\mid\left(\begin{array}{ll}0 & 1\end{array}\right)=12-9=3$ \\
\hline & Jadi. Det $A B C=3$ \\
\hline
\end{tabular}

Gambar 1. Jawaban siswa laki-laki pada tingkat memahami masalah

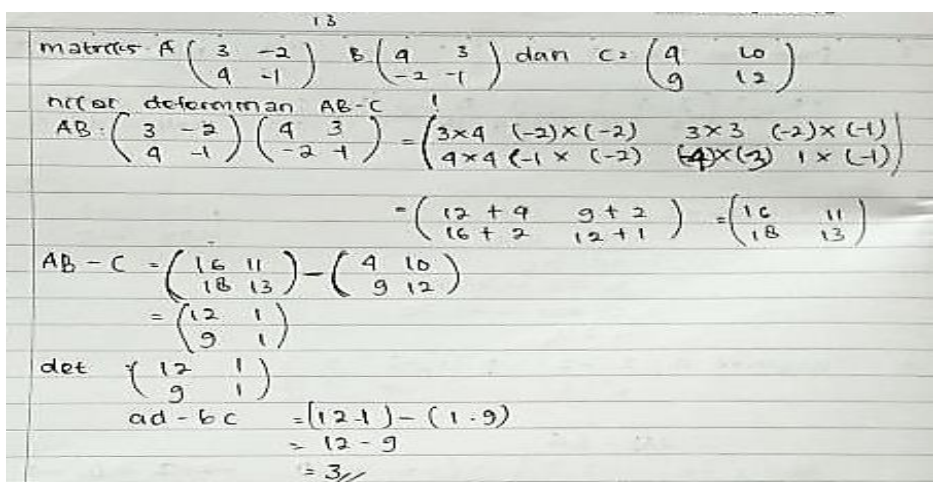

Gambar 2. Jawaban siswa perempuan pada tingkat memahami masalah 
DOI: https://doi.org/10.24127/ajpm.v10i2.3661

\subsection{Melaksanakan Rencana}

Berdasarkan hasil tes proses berpikir dalam pemecahan masalah matematis siswa untuk tingkat melaksanakan rencana dimana melaksanakan rencana disini yaitu siswa dapat merencanakan untuk memecahkan suatu masalah pada soal dengan menggunakan cara-cara yang telah dipelajari sebelumnya dengan guru. Kemudian mengaplikasikannya pada soal. Siswa perempuan dan laki-laki pada tingkat ini sudah dapat dikatakan mampu mencapai dengan baik karena terbukti pada jawaban siswa dibawah ini menunjukkan bahwa siswa mengaplikasikan apa yang telah guru ajarkan. Berikut merupakan salah satu contoh perwakilan dari jawaban siswa laki-laki (Gambar 3) dan jawaban siswa perempuan (Gambar 4) dalam tingkat melaksanakan rencana.

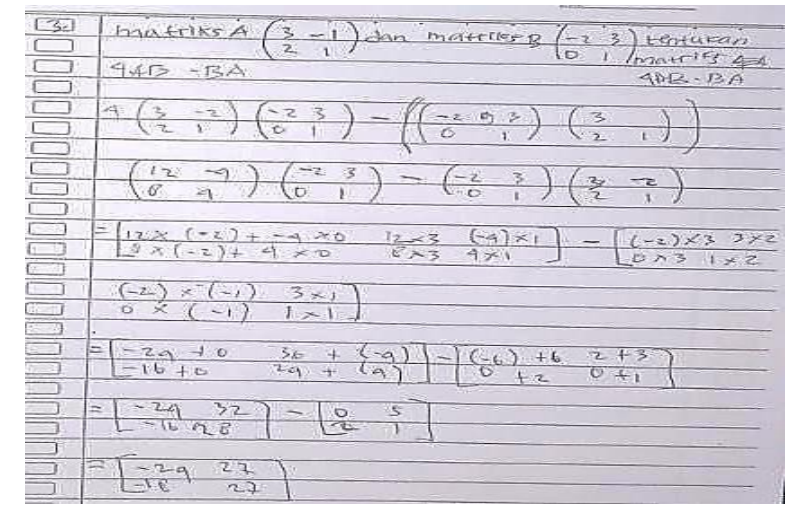

Gambar 3. Jawaban siswa laki laki tingkat melaksanakan rencana

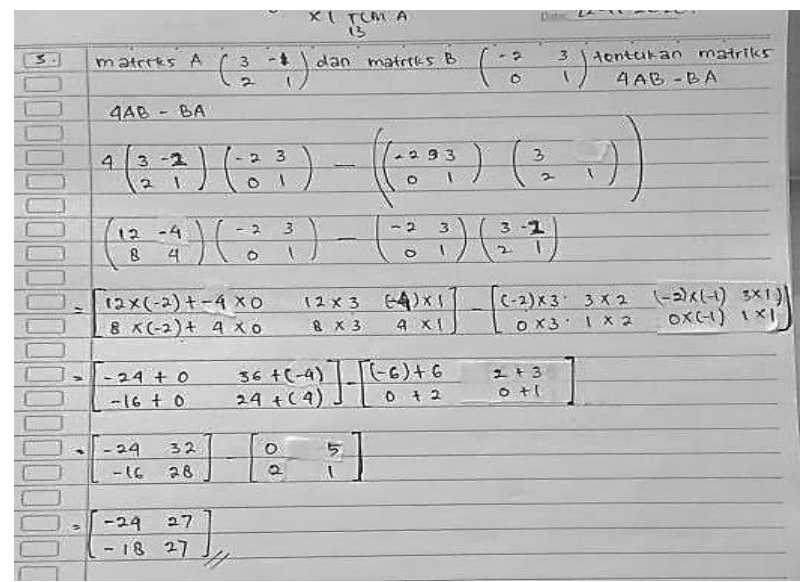

Gambar 4. Jawaban siswa perempuan tingkat melaksanakan rencana

\subsection{Merencanakan penyelesaian}

Berdasarkan hasil tes proses berpikir dalam pemecahan masalah matematis siswa untuk tingkat merencanakan penyelesaian, siswa laki-laki dan perempuan belum mampu menyimpulkan sesuatu yang ada menurut hasil yang telah diketahui yang sejalan dengan kondisi yang digambarkan, ini artinya siswa laki-laki dan perempuan belum mampu mencapai tingkat merencanakan penyelesaian. Berikut merupakan salah satu contoh perwakilan dari jawaban siswa laki-laki (Gambar 5) dan jawaban siswa perempuan (Gambar 6) dalam tingkat merencanakan penyelesaian. 
DOI: https://doi.org/10.24127/ajpm.v10i2.3661

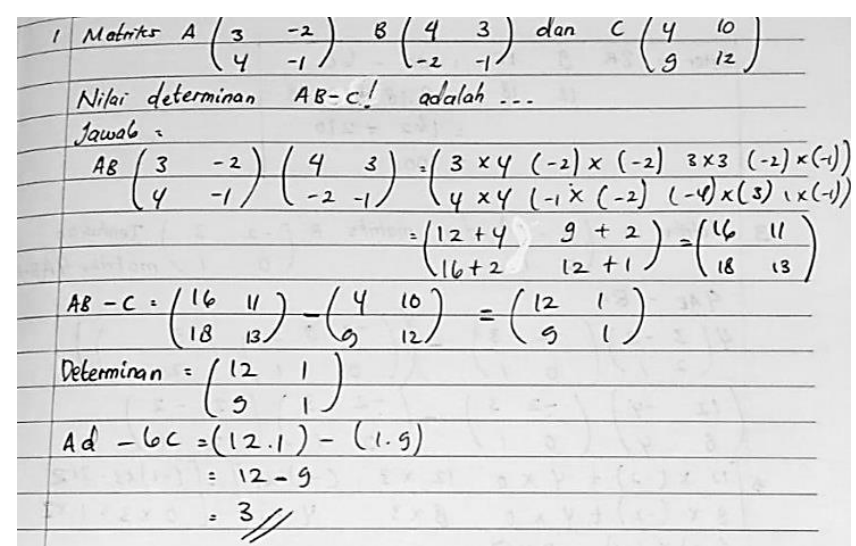

Gambar 5. Jawaban siswa laki laki tingkat merencanakan penyelesaian

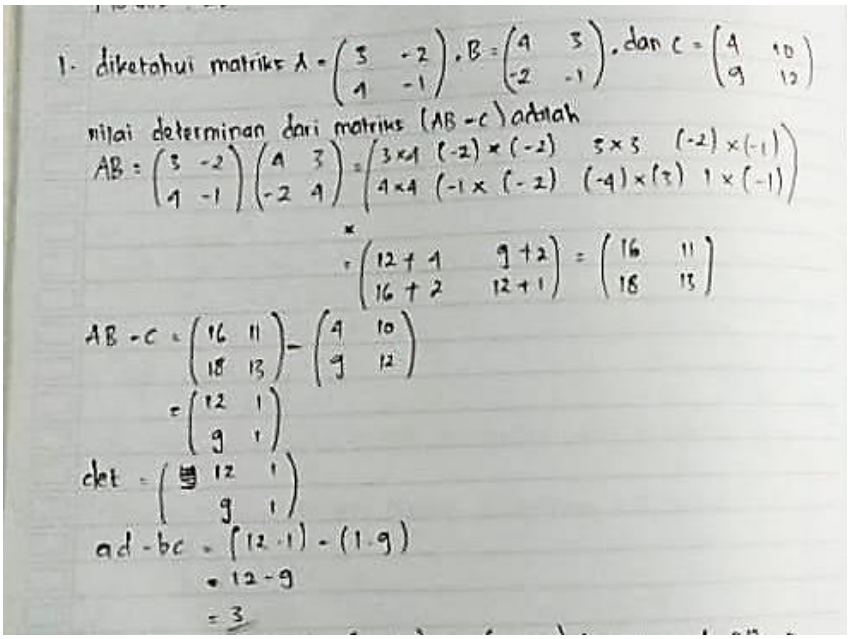

Gambar 6. Jawaban siswa perempuan tingkat merencanakan penyelesaian

1.4 Memeriksa proses dan hasil

Berdasarkan hasil tes proses berpikir dalam pemecahan masalah matematis siswa untuk tingkat memeriksa proses dan hasil, siswa perempuan lebih mampu mencapai tingkat memeriksa proses dan hasil terbukti dengan ketelitian yang ada pada jawaban siswa. Siswa laki-laki kurang teliti saat menghitung bilangan pada matriks pengurangan. Berikut merupakan salah satu contoh perwakilan jawaban siswa laki-laki (Gambar 7) dan jawaban siswa perempuan (Gambar 8) dalam tingkat merencanakan penyelesaian dalam tingkat memeriksa proses dan hasil.

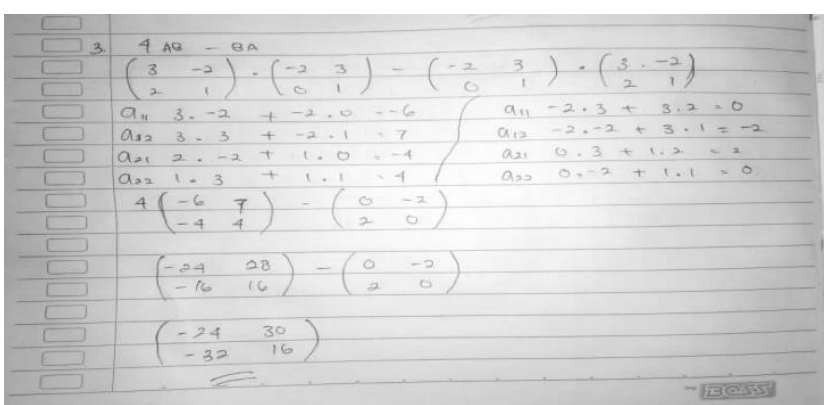

Gambar 7. Jawaban siswa laki laki tingkat memeriksa proses dan hasil 


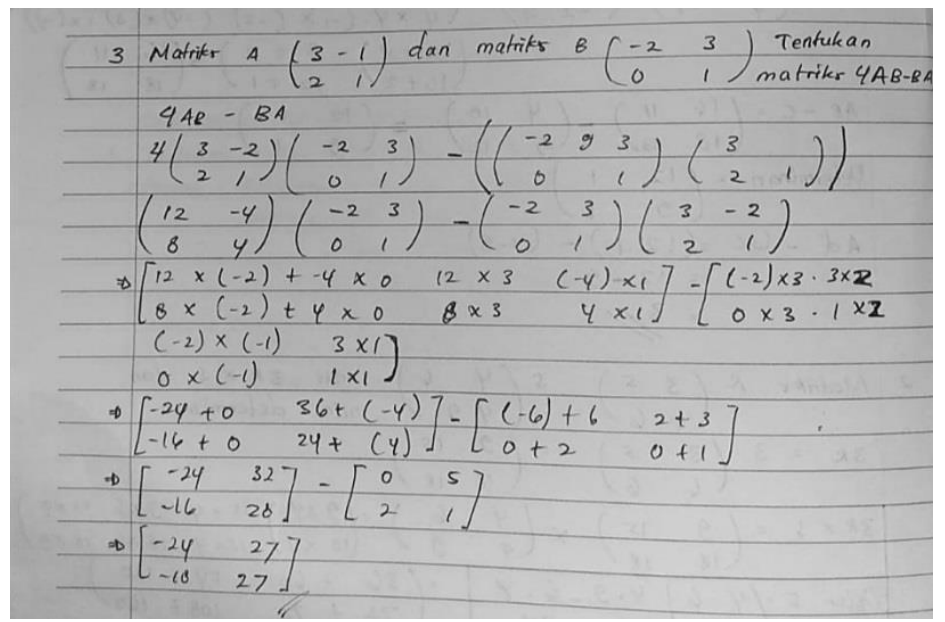

Gambar 8. Jawaban siswa perempuan tingkat memeriksa proses dan hasil

Berdasarkan hasil pemaparan diatas, diperoleh bahwa kemampuan siswa laki-laki dan perempuan tidaklah selalu sama. Pada gambar 1 dan 2 siswa perempuan masih belum bisa menerapkan langkah-langkah penyelesaian masalah matematika sesuai indikator yang digunakan pada penelitian ini namun untuk langkahlangkah berikutnya sudah sesuai indikator kemampuan pemecahan masalah begitu juga dengan siswa lakilaki pada gambar 1 dan 2 dimana siswa laki-laki sudah memahami langkahlangkah pemecahan masalah matematika sesuai indikator. Pada gambar 3 dan 4 siswa perempuan dan laki-laki sudah mampu menerapkan indikator melaksanakan rencana namun untuk indikator memahami masalah dan merencanakan penyelesaian dengan memberi simpulan dari apa yang diperoleh siswa belum mecapainya dengan baik harusnya siswa lebih teliti kembali pada saat menuliskan langkahlangkah penyelesaian masalah sesuai yang guru contohkan dengan memberi simpulan agar apa yang dicari pada soal terjawab dengan jelas. Pada gambar 5, 6, 7 dan 8 juga ditemukan kekurangan masing-masing jawaban seperti, belum memahami masalah dengan menuliskan diketahui, ditanyakan dan langkah apakah yang akan dipakai untuk menyelesaikan masalah. Namun yang dijumpai pada jawaban siswa rata-rata langsung pada indikator melaksanakan rencana. Pada saat menjawab soalpun siswa harus lebih teliti dengan cara melaksanakan langkah akhir penyelesaian masalah yaitu memeriksa kembali proses pekerjaan hingga hasil yang diperoleh agar tidak terjadi kesalahan dalam menghitung.

Pada dasarnya gender merupakan aspek psikososial yang menentukan cara seseorang bertindak dan berperilaku agar dapat diterima di lingkungan sosialnya. Perbedaan gender dapat menjadi faktor pembeda seseorang berpikir dan menentukan pemecahan masalah yang diambil. Ketika dihadapkan pada soal yang berbasis pemecahan masalah, siswa laki-laki dan perempuan memiliki kecenderungan pemecahan masalah yang berbeda, hal ini sejalan dengan pendapat oleh Nur dan Palobo pada penelitian terdahulu (Nur \& Palobo, 2018). Lebih lanjut Kartini Kartono dalam peneiltian yang dilakukan oleh Wahyudi, menyatakan bahwa adanya perbedaan-perbedaan antara laki-laki dan perempuan antara lain: perempuan pada umumnya perhatiannya tertuju pada hal-hal yang bersifat konkrit, praktis, emosional dan 
personal, sedangkan kaum laki-laki tertuju pada hal-hal yang yang bersifat intelektual, abstrak dan objektif (Iswahyudi, 2012). Kemampuan pemecahan masalah matematika antara laki-laki dan perempuan memiliki perbedaan, hal ini sejalan dengan penelitian terdahulu yang dilakukan oleh Davita dan Pujiastuti, perbedaanya terletak dari bagaimana cara siswa lakilaki dan siswa perempuan dalam menyelesaikan soal, sehingga terjadi kesenjangan antara tingkat partisipasi laki-laki dan perempuan (Davita \& Pujiastuti, 2020).

\section{KESIMPULAN DAN SARAN}

Berdasarkan hasil dan diskusi, dengan mengacu pada indikator pemecahan masalah dapat disimpulkan bahwa pada tingkat memahami masalah, siswa laki-laki lebih baik dari pada perempuan sehingga siswa lakilaki mampu mencapai tingkat memahami masalah dengan baik sehingga mampu menyebutkan apa yang diketahui dan ditanyakan pada soal dengan jelas. Pada tingkat melaksanakan rencana, Siswa perempuan dan laki-laki sudah dapat dikatakan mampu mencapai dengan baik karena terbukti pada jawaban siswa yang menunjukkan bahwa siswa mengaplikasikan apa yang telah guru ajarkan. Pada tingkat merencanakan penyelesaian, siswa laki-laki dan perempuan belum mampu menyimpul-kan sesuatu yang ada menurut hasil yang telah diketahui maka belum mampu mencapai tingkat merencanakan penyelesaian. Pada tingkat memeriksa proses dan hasil, siswa perempuan lebih mampu mencapai tingkat memeriksa proses dan hasil terbukti dengan ketelitian yang ada pada jawaban siswa. Siswa laki-laki kurang teliti saat menghitung bilangan pada matriks pengurangan.
Hasil penelitian ini dapat digunakan sebagai bahan untuk perbandingan dan referensi serta sebagai bahan pertimbangan untuk penelitain selanjutnya pada kemampuan pemecahan masalah yang ditinjau dari gender. Penelitian selanjutnya diharapkan dapat mengembangkan lebih luas lagi untuk mencari solusi terbaik untuk meningkatkan kemampuan pemecahan masalah matematika siswa.

\section{DAFTAR PUSTAKA}

Agoestanto, Arief, \& Safitri, S. N. (2013). Keefektifan Pembelajaran Matematika Mengacu Pada Missouri Mathematics Project Terhadap Kemampuan Pemecahan Masalah. Prosiding Seminar Nasional Matematika VII UNNES, 71-77.

Azizah, F. R. (2015). Analisis Kemampuan Pemecahan Masalah Matematika Berdasarkan Taksonomi SOLO pada Sub Pokok Bahasan Balok Siswa Kelas VIII-H SMP, 1-241.

Budiyono. (2017). Pengantar Metodologi Penelitian Pendidikan. Surakarta: UNS Press.

Capriora, D. (2015). Problem SolvingPurpose and Means of Learning Mathematics in School. ProcediaSocial and Behavioral Sciences, 1(9), 1859-1864.

Davita, P. W. C., \& Pujiastuti, H. . (2020). Anallisis Kemampuan Pemecahan Masalah Matematika Ditinjau Dari Gender. Kreano: Jurnal Matematika KreatifInovatif, 11(1), 110-117.

Diandita, E. R., Johar, R., \& Abidin, T. F. (2017). Kemampuan Komunikasi Matematis Dan Metakognitif Siswa SMP Pada Materi Lingkaran Berdasarkan 
DOI: https://doi.org/10.24127/ajpm.v10i2.3661

Gender. Jurnal Pendidikan Matematika, 11(2), 79-97.

Fitriani, Y., Jalmo, T., \& Yolida, B. (2015). Hubungan Antara Gender Dengan Kemampuan Memecahkan Masalah. Jurnal Bioterdidik: Wahana Ekspresi Ilmiah, 3(5), 1-11.

Gunur, B., Alberta, \& Apolonia. (2018). Hubungan Antara Kemampuan Numerik dengan Kemampuan Pemecahan Masalah Matematis Siswa di Pedesaan. MaPan: Jurnal Matematika Dan Pembelajaran, 6(2), 148-160.

Gurun, J., Kubang, A., \& Agam, P. (2018). Profil Kemampuan Spasial Mahasiswa Camper Dalam Merekonstruksi Irisan Prisma Ditinjau Dari Perbedaan Gender. MaPan: Jurnal Matematika Dan Pembelajaran, 6(1), 31-39.

Imamah, F. U., \& Toheri. (2014). Pengaruh Penggunaan Kombinasi Metode Pembelajaran Discovery Learning Dan Brain Storming Terhadap Kemampuan Pemecahan Masalah Pada Pokok Bahasan Himpunan. EduMa, 3(1), 120-137.

Iswahyudi, G. (2012). Aktivitas Metakognisi dalam Memecahkan Masalah Pembuktian Langsung Ditinjau dari Gender dan Kemampuan Matematika. In Seminar Nasional Pendidikan Matematika UNS Surakarta. Surakarta.

Kusumawati, S. W. (2014). Penerapan Model Pembelajaran SAVI Untuk Meningkatkan Keterampilan Pemecahan Masalah di Sekolah Dasar. JPGSD, 2(2), 1-10.

Mita, D. S., Tambunan, L. R., \& Izzati, N. (2019). Analisis Kemampuan Pemecahan Masalah Peserta Didik
Dalam Menyelesaikan Soal PISA. Lentera Sriwijaya: Jurnal Ilmiah Pendidikan Matematika, 1(2), 2533.

Ngaeni, E. N., \& Saefudin, A. A. (2017). Menciptakan Pembelajaran Matematika yang Efektif Dalam Pemecahan Masalah Matematika Dengan Model pembelajaran Problem Posing. Jurnal Aksioma, 6(2), 264-274.

Nur, A. S., \& Palobo, M. (2018). Profil Kemampuan Pemecahan Masalah Matematika Siswa Ditinjau dari Perbedaan Gaya Kognitif dan Gender. Jurnal Matematika Kreatif-Inovatif, 9(2), 139-148.

Nurhayati, E., Mulyana, T., \& Martadiputra, B. A. P. (2016). Penerapan scaffolding untuk pencapaian kemampuan pemecahan masalah matematis. Jurnal Penelitian Pendidikan Dan Pengajaran Matematika, 2(2), 107-112.

Putra, M., \& Novita, R. (2014). Pemecahan Masalah Matematika Tipe PISA Pada Siswa Sekolah Menengah Dengan Konten Hubungan dan Perubahan. Jurnal MAJU (Jurnal Pendidikan Matematika), 1(1), 37-46.

Rahayuningsih, S., \& Feriyanto. (2018). Analisis Proses Berpikir Mahasiswa dalam Memecahkan Masalah Grup Ditinjau dari Gender. Jurnal Pendidikan: Teori, Penelitian, Dan Pengembangan, 3(12), 1672-1681.

Ramadhani, R. (2017). Kemampuan Pemecahan Masalah Matematika Siswa SMA Melalui Guided Discovery Learning Berbantuan Autograph. JPPM, 10(2), 72-81.

Simanjuntak, E., Hia, Y., \& Manurung, N. (2019). Analisis Kemampuan 
DOI: https://doi.org/10.24127/ajpm.v10i2.3661

Berpikir Kreatif Dalam Pemecahan Masalah Ditinjau Dari Gender. School Education Journal, 9(3), 213-220.

Siswati, B. H., Susilo, H., \& Mahanal, S. (2016). Pengaruh Gender Terhadap Keterampilan Metakognitif dan Pemahaman Konsep Peserta Didik IPA dan Biologi di Malang. In Pros. Semnas Pend. IPA Pascasarjana $U M$ (pp. 748-755).

Subarinah. (2013). Profil Berpikir Kreatif Siswa dalam Memecahkan Masalah Tipe Investigasi Matematik Ditinjau dari Perbedaan Gender. In Seminar Nasional Matematika dan Pendidikan Matematika UNY (pp. 541-548). Yogyakarta: Universitas Negeri Yogyakarta.

Tao, H.-L., \& Michalopoulos, C. (2020). Gender Equality And The Gender Gap In Mathematics. $J$. Biosoc. Sci., 50(3), 227-243. https://doi.org/10.1017/S0021932 017000141

Utami, C., \& Anitra, R. (2020). Kemampuan Pemahaman Konsep Siswa Berdasarkan Gender pada Pembelajaran Realistic Mathematics Education Berbantuan Alat Peraga PANDU. Jurnal Kependidikan: Jurnal Hasil Penelitian Dan Kajian Kepustakaan Di Bidang Pendidikan, Pengajaran Dan Pembelajaran, 6(3), 475-489.

Winata, R., \& Friantini, R. N. (2020). Kemampuan Pemahaman Konsep Matematika Siswa Ditinjau Dari Minat Belajar Dan Gender. Journal of Mathematics Education, 6(1), 1-18.
Yurniati, \& Wahyuningrum, E. (2015). Pembelajaran Berbasis ICARE Dalam Tutorial Online Untuk Meningkatkan Kemampuan Pemecahan Masalah Matematis Mahasiswa UT. Infinity, 4(2), 182-189. 